\title{
Immunosupressive Properties of HLA-G Molecules Produced by Mesenchymal Stromal Cells
}

\section{Roberta Rizzo*}

Department of Medical Sciences, Section of Microbiology and Medical Genetics, University of Ferrara, Ferrara, Italy

\begin{abstract}
The main interest in human mesenchymal stromal cells (hMSCs) is correlated with their ability to suppress the proliferation of immune cells and to regulate the transplantation rejection. The mechanisms at the basis of MSCs activity need cell-cell interaction and the expression of molecules induced by the micro-environment. The inhibitory functions of MSCs involve several molecules as hepatocyte growth factor, transforming growth factor-beta (TGF-beta), interleukin-10 and -2 (IL-10, IL-2), tumour necrosis factor-alpha (TNF-alpha), prostaglandin E2 (PGE2), indoleamine 2,3-dioxygenase (IDO), and HLA-G antigens. A large consesus has been obtained on the immune-modulatory role of HLA-G molecules produced by hMSCs.
\end{abstract}

\section{Keywords: Mesenchymal stromal cells; HLA-G; Immunosuppression}

Human multipotent mesenchymal stromal cells (hMSCs), first described by Friedenstein in '70 years [1] as non-hematopoietic cell precursors with osteogenic potential, represent stem cells for nonhematopoietic tissues [2]. The functional and immunophenotic characteristics of stromal cells have been recently reviewed and redefined by International Society for Cellular Therapy (ISCT) [3]: they must be defined as hMSCs, which are a plastic adherent cell population that retain in vitro clonogenic potential (defined by the presence of the fibroblast-colony forming unit, (CFU-F), capable of supporting hematopoiesis and having a differentiation capacity towards a number of different cell types (osteoblasts, chondrocytes, adipocytes, myocytes).

In the last years several studies have demonstrated the peculiar immunological characteristics of hMSCs, as low antigenicity and high immunomodulatory ability, suggesting their clinical use to counteract rejection in regenerative medicine and tissue transplantation. Cultured allogeneic hMSCs are widely used in clinical trials in hematopoietic stem cell infusion [4-6], in solid-organ transplantation [7] and for treating autoimmune diseases [8,9]. However, the in vivo data are still controversial and a specific marker for hMSCs selection is needed. The low antigenicity of hMSCs is mainly caused by the low expression of classical HLA (human leukocyte antigen) class I molecules and the complete absence of HLA class II antigens and co-stimulatory molecules as CD80 (B7-1), CD86 (B7-2) and CD40 [10]. The main interest in hMSCs is correlated with their ability to suppress the proliferation of $\mathrm{T}$ lymphocytes induced by mitogenic agents and alloantigens which regulate the transplantation rejection [11]. Moreover, hMSCs are resistant to the $\mathrm{CD} 8+\mathrm{T}$ lymphocyte cytotoxicity, they are able to inhibit the differentiation of dendritic cells responsible for the antigen presentation, the proliferation and antibody production of $\mathrm{B}$ lymphocytes and they stimulate the formation of regulatory $\mathrm{T}$ cells. The mechanisms at the basis of hMSCs activity need cell-cell interaction and the production of molecules induced by the micro-environment. The inhibitory functions of hMSCs involve several molecules as hepatocyte growth factor, transforming growth factor-beta (TGFbeta), interleukin-10 and -2 (IL-10, IL-2), tumour necrosis factor-alpha (TNF-alpha), prostaglandin E2 (PGE2), indoleamine 2,3-dioxygenase (IDO) [12] and HLA-G antigens [13]. A large consesus has been obtained on the immuno-modulatory role of HLA-G molecules.

HLA-G antigen is a non-classical HLA class I molecule characterized by 7 mRNA splicing isoforms, 4 membrane-bound (HLA-G1, G2, G3, G4) and 3 soluble (HLA-G5, G6, G7). Both soluble and membranebound isoforms are able to inhibit several immune functions as lytic and cytotoxic activity of Natural Killer (NK) cells and T CD8+ lymphocytes, the maturation of dendritic cells, and the alloproliferation of CD4+ T lymphocytes and to induce the formation of regulatory $\mathrm{T}$ cells. HLA-G molecules differ from classical HLA antigens for their lower allelic polymorphism (50 alleles, http://hla.alleles.org/class1. $\mathrm{html}$ ) and the limited tissue distribution. HLA-G expression is induced in pathological conditions, as tumours and viral infections [14]. Taking into consideration the tolerogenic functions of HLA-G molecules, they could be a good candidate as a factor for hMSCs immuno-modulatory activity. Götherström et al. [15] have demonstrated the presence of HLA-G mRNA in both fetal and adult hMSCs. The modulation of HLA-G has been documented on the surface of hMSCs [16] and in their culture supernatants [17]. Several studies have confirmed that the cell-cell contact between hMSCs and T lymphocyte induces the secretion of HLA-G molecules and IL-10, a cytokine that is able to upmodulate HLA-G production [17]. The use of neutralizing antibodies against HLA-G and IL-10 have demonstrated the importance of soluble HLA-G, induced by IL-10, for the suppressive effect of hMSCs towards cell proliferation $[18,19]$, cytotoxic activity and IFN- $\gamma$ secretion by NK cells, and the ability to induce regulatory T CD $4^{+} \mathrm{CD} 25^{\text {high }} \mathrm{FoxP}^{+}$ cells formation [20]. These data suggest a fundamental role for HLA-G antigens in the tolerogenic function of hMSCs.

The selective use of HLA-G positive hMSCs could be a valuable tool in improving current protocols of hMSCs use as immunosuppressant cell biotherapy [21]. In fact, stable HLA-G expression by lentiviral system in hMSCs appeared to enhance the immunosuppressive effect of MSCs [22].

In conclusion, hMSCs are newly detected targets for immunomodulatory activity and HLA-G molecules could be an important factor of this mechanism.

*Corresponding author: Roberta Rizzo, Department of Medical Sciences, Section of Microbiology and Medical Genetics, University of Ferrara, Via Luig Borsari, 46, I-44121 Ferrara, Italy, Tel: +390532455382; Fax +390532974470 E-mail:rbr@unife.it

Received November 21, 2013; Accepted November 21, 2013; Published November 23, 2013

Citation: Rizzo R (2013) Immunosupressive Properties of HLA-G Molecules Produced by Mesenchymal Stromal Cells. J Transplant Technol Res 3: e127. doi:10.4172/2161-0991.1000e127

Copyright: (c) 2013 Rizzo R. This is an open-access article distributed under the terms of the Creative Commons Attribution License, which permits unrestricted use, distribution, and reproduction in any medium, provided the original author and source are credited. 
Citation: Rizzo R (2013) Immunosupressive Properties of HLA-G Molecules Produced by Mesenchymal Stromal Cells. J Transplant Technol Res 3: e127. doi:10.4172/2161-0991.1000e127

Page 2 of 2

\section{References}

1. Friedenstein AJ, Chailakhjan RK, Lalykina KS (1970) The development of fibroblast colonies in monolayer cultures of guinea-pig bone marrow and spleen cells. Cell Tissue Kinet 3: 393-403.

2. Prockop DJ (1997) Marrow stromal cells as stem cells for nonhematopoietic tissues. Science 276: 71-74.

3. Dominici M, Le Blank K, Mueller I, Slaper-Cortenbach I, Marini F, et al. (2006) Position paper: Minimal criteria for defining multipotent mesenchymal stromal cells. The International Society for Cellular Therapy position statement. Cytotherapy 8: 315-317.

4. Le Blanc K, Frassoni F, Ball L, Locatelli F, Roelofs H, et al. (2008) Mesenchymal stem cells for treatment of steroid-resistant, severe, acute graft-versus-host disease: a phase II study. Lancet 371: 1579-1586.

5. Kuzmina LA, Petinati NA, Parovichnikova EN, Lubimova LS, Gribanova EO, et al. (2012) Multipotent Mesenchymal Stromal Cells for the Prophylaxis of Acute Graft-versus-Host Disease-A Phase II Study. Stem Cells Int 2012: 968213.

6. Herrmann R, Sturm M, Shaw K, Purtill D, Cooney J, et al. (2012) Mesenchymal stromal cell therapy for steroid-refractory acute and chronic graft versus host disease: a phase 1 study. Int J Hematol 95: 182-188.

7. Hoogduijn MJ, Popp FC, Grohnert A, Crop MJ, van Rhijn M, et al. (2010) Advancement of mesenchymal stem cell therapy in solid organ transplantation (MISOT). Transplantation 90: 124-126.

8. Ricart E (2012) Current status of mesenchymal stem cell therapy and bone marrow transplantation in IBD. Dig Dis 30: 387-391.

9. Zanone MM, Favaro E, Miceli I, Grassi G, Camussi E, et al. (2010) Human mesenchymal stem cells modulate cellular immune response to islet antigen glutamic acid decarboxylase in type 1 diabetes. J Clin Endocrinol Metab 95: 3788-3797.

10. Le Blanc K, Tammik C, Rosendahl K, Zetterberg E, Ringdén O (2003) HLA expression and immunologic properties of differentiated and undifferentiated mesenchymal stem cells. Exp Hematol 31: 890-896.

11. Tse WT, Pendleton JD, Beyer WM, Egalka MC, Guinan EC (2003) Suppression of allogeneic T-cell proliferation by human marrow stromal cells: implications in transplantation. Transplantation 75: 389-397.
12. Meisel R, Zibert A, Laryea M, Göbel U, Däubener W, et al. (2004) Human bone marrow stromal cells inhibit allogeneic T-cell responses by indoleamine 2,3-dioxygenase-mediated tryptophan degradation. Blood 103: 4619-4621.

13. Rizzo R, Campioni D, Stignani M, Melchiorri L, Bagnara GP, et al. (2008) A functional role for soluble HLA-G antigens in immune modulation mediated by mesenchymal stromal cells. Cytotherapy 10: 364-375.

14. Rizzo R, Bortolotti D, Baricordi OR, Fainardi E (2012) New insights into HLA-G and inflammatory diseases. Inflamm Allergy Drug Targets 11: 448-463.

15. Götherström C, West A, Liden J, Uzunel M, Lahesmaa R, et al. (2005) Difference in gene expression between human fetal liver and adult bone marrow mesenchymal stem cells. Haematologica 90: 1017-1026.

16. Nasef A, Mathieu N, Chapel A, Frick J, François S, et al. (2007) Immunosuppressive effects of mesenchymal stem cells: involvement of HLA-G. Transplantation 84: 231-237.

17. Rizzo R, Lanzoni G, Stignani M, Campioni D, Alviano F, et al. (2011) A simple method for identifying bone marrow mesenchymal stromal cells with a high immunosuppressive potential. Cytotherapy 13: 523-527.

18. Stubbendorff M, Deuse T, Hua X, Phan TT, Bieback K, et al. (2013) Immunological properties of extraembryonic human mesenchymal stromal cells derived from gestational tissue. Stem Cells Dev 22: 2619-2629.

19. Najar M, Raicevic G, Fayyad-Kazan H, De Bruyn C, Bron D, et al. (2012) Immune-related antigens, surface molecules and regulatory factors in humanderived mesenchymal stromal cells: the expression and impact of inflammatory priming. Stem Cell Rev 8: 1188-1198.

20. Selmani Z, Naji A, Zidi I, Favier B, Gaiffe E, et al. (2008) Human leukocyte antigen-G5 secretion by human mesenchymal stem cells is required to suppress T lymphocyte and natural killer function and to induce CD4+CD25highFOXP3+ regulatory T cells. Stem Cells 26: 212-222.

21. Naji A, Rouas-Freiss N, Durrbach A, Carosella ED, Sensébé L, et al. (2013) Concise review: combining human leukocyte antigen $\mathrm{g}$ and mesenchymal stem cells for immunosuppressant biotherapy. Stem Cells 31: 2296-2303.

22. Yang HM, Sung JH, Choi YS, Lee HJ, Roh CR, et al. (2012) Enhancement of the immunosuppressive effect of human adipose tissue-derived mesenchymal stromal cells through HLA-G1 expression. Cytotherapy 14: 70-79. 